\title{
Flocculating performance of a bioflocculant produced by Arthrobacter humicola in sewage waste water treatment
}

\author{
Mayowa Oladele Agunbiade ${ }^{1,2^{*}}$, Esta Van Heerden ${ }^{2}$, Carolina H. Pohl ${ }^{2}$ and Anofi Tom Ashafa ${ }^{1}$
}

\begin{abstract}
Background: The discharge of poorly treated effluents into the environment has far reaching, consequential impacts on human and aquatic life forms. Thus, we evaluated the flocculating efficiency of our test bioflocculant and we report for the first time the ability of the biopolymeric flocculant produced by Arthrobacter humicola in the treatment of sewage wastewater. This strain was isolated from sediment soil sample at Sterkfontein dam in the Eastern Free State province of South Africa.

Results: Basic Local Alignment Search Tool (BLAST) analysis of the nucleotide sequence of the $16 \mathrm{~S}$ rDNA revealed the bacteria to have $99 \%$ similarity to Arthrobacter humicola strain R1 and the sequence was deposited in the Gene bank as Arthrobacter humicola with accession number KC816574.1. Flocculating activity was enhanced with the aid of divalent cations, $\mathrm{pH}$ 12, at a dosage concentration of $0.8 \mathrm{mg} / \mathrm{mL}$. The purified bioflocculant was heat stable and could retain more than $78 \%$ of its flocculating activity after heating at $100{ }^{\circ} \mathrm{C}$ for $25 \mathrm{~min}$. Fourier Transform Infrared Spectroscopy analysis demonstrated the presence of hydroxyl and carboxyl moieties as the functional groups. The thermogravimetric analysis was used to monitor the pyrolysis profile of the purified bioflocculant and elemental composition revealed C: O: Na: P: K with 13.90: 41.96: 26.79: 16.61: 0.74 weight percentage respectively. The purified bioflocculant was able to remove chemical oxygen demand, biological oxygen demand, suspended solids, nitrate and turbidity from sewage waste water at efficiencies of $65.7 \%, 63.5 \%, 55.7 \%, 71.4 \%$ and $81.3 \%$ respectively.
\end{abstract}

Conclusions: The results of this study indicate the possibility of using the bioflocculant produced by Arthrobacter humicola as a potential alternative to synthesized chemical flocculants in sewage waste water treatment and other industrial waste water.

Keywords: Purified bioflocculant, Arthrobacter humicola, Sewage waste water, FTIR, Flocculating activity

\section{Background}

The discharge of untreated or partially treated waste water accounts for the majority of health related issues in human beings and aquatic life forms. When pollutants from waste water are discharged into natural water bodies, the water bodies become contaminated and toxic and may consequently pose a major threat to human

\footnotetext{
*Correspondence: mayorlala@gmail.com

'Phytomedicine and Phytopharmacology Research Group, Department of Plant Sciences, University of the Free State, Qwaqwa Campus, P. Bag X13, Phuthaditjabha 9866, South Africa

2Department of Microbial, Biochemical \& Food Biotechnology, University of the Free State, P.O. Box 339, Nelson Mandela Drive, Bloemfontein 9301, South Africa
}

(c) The Author(s). 2017 Open Access This article is distributed under the terms of the Creative Commons Attribution 4.0 International License (http://creativecommons.org/licenses/by/4.0/), which permits unrestricted use, distribution, and reproduction in any medium, provided you give appropriate credit to the original author(s) and the source, provide a link to the Creative Commons license, and indicate if changes were made. The Creative Commons Public Domain Dedication waiver (http://creativecommons.org/publicdomain/zero/1.0/) applies to the data made available in this article, unless otherwise stated.

beings. Water contains about $78 \%$ of the earth's surface which is a source of life and energy. However millions of people doesn't have access to safe water for drinking purposes and human utilization as a result of human negligence [1]. Hence, toxic and polluted material from the waste water must be well treated or removed prior to discharge into the environment [2]. Although, settling separation techniques has been widely adopted in most factories to recover suspended solid materials in waste water, the process is however time consuming and the separation efficiency is low. Consequently, the need for the use of flocculants which appear to be gaining global acceptance for various industrial processes such as treatment of potable water, waste water treatment and 
downstream processes in fermentation industries has been well appreciated [3]. A review of the literature shows that the use of inorganic and organic flocculants in various industrial and wastewater treatment processes is increasing [4-7]. However, despite the fact that organic and inorganic synthetic flocculants are cost effective, they are non-biodegradable and have been implicated in health related issues. For instance, polyacrylamide that contain acrylamide monomers are neurotoxic and carcinogenic [8]. Also, aluminium, which is a major component of polyaluminium chloride is known to be a contributing factor in Alzheimer's syndrome. Based on the adverse health related issues attributed to the usage of chemically synthesized flocculants in the process of flocculation, there is need to employ microbial flocculants which are biodegradable and environmentally friendly that will serve as alternatives to chemical flocculants. Biodegradable bioflocculants have been isolated from different environments as natural byproducts of the growth of certain bacteria, fungi, algae and actinomycetes during their growth $[9,10]$. Bioflocculants enhance the formation and settlement of sludge treatment systems and have the potential to provide better applications in relevant industries and wastewater treatment $[11,12]$. Microbial flocculants with different functional properties, particularly those that are mainly polysaccharide, have been found to be useful as stabilizers, film forming agents, water retention agents, lubricants and friction reducers in many industries like textiles, adhesives, paper, paint, food, pharmaceuticals, cosmetics, detergents and in laundry products.

The genus Arthrobacter, found in the soil, is an obligate aerobic bacterium. This genus has found biotechnological importance in degrading organic pollutants such as phenols, chlorophenols, benzene, toluene, ethylbenzene, xylene and phenanthrene [13, 14]. It has also been reported as a potential microbial flocculant in flocculation. In spite of the flocculating potentials of this genus, there is dearth of information on the specific bioflocculant produced by Arthrobacter humicola for sewage waste water treatment. Hence, this study optimized the culture conditions and evaluated the flocculating potential of Arthrobacter humicola in sewage waste water treatment.

\section{Methods}

\section{Collection of sample and isolation of bioflocculant- producing microorganism}

Soil sediment samples were collected aseptically from Sterkfontein dam in the Eastern Free State Province of South Africa and transported to the laboratory in a cooler box containing an ice pack. Exactly 20 grams of each sediment sample was air-dried at room temperature for two to three days, crushed, sieved through a $2 \mathrm{~cm}$ mesh and kept refrigerated $\left(4{ }^{\circ} \mathrm{C}\right)$ until use. The cultivation of actinomycetes from the processed sediment samples was done as previously described [15]. This involved the use of Yeast Malt Extract agar (YMA) (4 g/L yeast extract, $10 \mathrm{~g} / \mathrm{L}$ malt extract, $4 \mathrm{~g} / \mathrm{L}$ glucose, $16 \mathrm{~g} / \mathrm{L}$ bacteriological agar) supplemented with $50 \mathrm{mg} / \mathrm{L}$ cyclohexamide and $20 \mathrm{mg} / \mathrm{L}$ nalidixic acid to inhibit the growth of bacteria and fungi species respectively. Subsequently, an aliquot $(100 \mu \mathrm{L})$ of the sediment sample suspension was spread over the cultivation medium and incubated at $28{ }^{\circ} \mathrm{C}$ for two weeks. Typical colonies were purified by streaking on fresh YMA plates.

\section{Screening and culturing of bioflocculant-producing actinomycetes}

The adapted protocol of Xia et al. [16] was used to screen the ten isolated actinomycete strains for bioflocculant production. The isolates were inoculated into $250 \mathrm{~mL}$ Erlenmeyer flask containing $50 \mathrm{~mL}$ of screening medium $[20 \mathrm{~g} / \mathrm{L}$ glucose, $0.5 \mathrm{~g} / \mathrm{L}$ urea, $0.5 \mathrm{~g} / \mathrm{L}$ yeast extract, $0.2 \mathrm{~g} / \mathrm{L}$ $\left(\mathrm{NH}_{4}\right)_{2} \mathrm{SO}_{4}, 0.1 \mathrm{~g} / \mathrm{L} \mathrm{NaCl}, 0.2 \mathrm{~g} / \mathrm{L} \mathrm{MgSO}_{4} \cdot 7 \mathrm{H}_{2} \mathrm{O}, 5 \mathrm{~g} / \mathrm{L}$ $\left.\mathrm{K}_{2} \mathrm{HPO}_{4}, 2 \mathrm{~g} / \mathrm{L} \mathrm{KH}_{2} \mathrm{PO}_{4}\right]$ and incubated $\left(30{ }^{\circ} \mathrm{C}, 160 \mathrm{rpm}\right)$ on a rotary shaker for $48 \mathrm{~h}$. This pre-culture was then used as the standard inoculum for subsequent experiments. Erlenmeyer flasks $(250 \mathrm{~mL})$ containing $50 \mathrm{~mL}$ production medium $(10 \mathrm{~g} / \mathrm{L}$ glucose, $1 \mathrm{~g} / \mathrm{L}$ yeast extract, $0.3 \mathrm{~g} / \mathrm{L}$ $\mathrm{MgSO}_{4} .7 \mathrm{H}_{2} \mathrm{O}, 5 \mathrm{~g} \mathrm{~K}_{2} \mathrm{HPO}_{4}, 2 \mathrm{~g} / \mathrm{L} \mathrm{KH}_{2} \mathrm{PO}_{4}$ was inoculated with $100 \mu \mathrm{L}$ of the pre-culture suspension and further incubated $\left(25^{\circ} \mathrm{C}, 130 \mathrm{rpm}\right)$ in a rotary shaker for $48 \mathrm{~h}$. After incubation, cell free culture supernatants were obtained by centrifugation and used to determine bioflocculant activity against kaolin clay suspension.

\section{Determination of flocculating activity}

Flocculating activity was determined using the protocol of Kurane et al. [17]. A volume of $100 \mathrm{~mL}$ of kaolin clay suspension $(4 \mathrm{~g} / \mathrm{L})$ was added to $2 \mathrm{~mL}$ of the supernatant and $3 \mathrm{~mL}$ of calcium chloride $(1 \% \mathrm{w} / \mathrm{v})$ in $250 \mathrm{~mL}$ conical flasks. The mixture was shaken thoroughly for $30 \mathrm{~s}$ and gently poured into $100 \mathrm{~mL}$ measuring cylinder and allowed to stand for $5 \mathrm{~min}$. Following this, the optical density (OD) of the clarifying solution was measured using a spectrophotometer (UV/Visible Biowave II and Biowave $\mathrm{II}^{+}$England) at $550 \mathrm{~nm}$. The control experiment was conducted in the same way, but cell free supernatant was replaced with $2 \mathrm{~mL}$ of the production medium. The flocculating activity (FA) was calculated using the equation;

$$
F A(\%)=\frac{B-A}{B} \times 100
$$

Where: $\mathrm{A}$ and $\mathrm{B}$ are the respective absorbance of the sample and control experiment at $550 \mathrm{~nm}$. 
The strain that displayed the highest flocculating activity was selected for further investigation.

\section{Identification of organism DNA extraction}

The genomic DNA of the strain was extracted using a ZR fungal/bacteria DNA preparation kit according to the manufacturer's instructions.

\section{Amplification of 16S rRNA gene}

The 16S rRNA gene was amplified using universal primers 27f: $\left(5^{1}\right.$ - GAGTTTGATCCTGGCTCAG - $\left.3^{1}\right)$ 1492r: $\left(5^{1}\right.$ - GGTTACCTTGTTACGACT - $\left.3^{1}\right)$ Lane [15]. PCR amplification was carried out in $20 \mu \mathrm{L}$ reaction volume containing $10 \mu \mathrm{L}$ of Econo PCR master mix, $1 \mathrm{mM}$ of each primer, $1 \mu \mathrm{L}$ of template DNA. Subsequently, $8 \mu \mathrm{L}$ sterile distilled PCR grade water was added to a final volume of $20 \mu \mathrm{L}$. The PCR program used was an initial denaturation $\left(94{ }^{\circ} \mathrm{C}\right.$ for $\left.5 \mathrm{~min}\right), 45$ cycles of denaturation $\left(94{ }^{\circ} \mathrm{C}\right.$ for $\left.30 \mathrm{~s}\right)$, annealing $\left(55^{\circ} \mathrm{C}\right.$ for $\left.30 \mathrm{~s}\right)$, extension $\left(72{ }^{\circ} \mathrm{C}\right.$ for $\left.1 \mathrm{~min}, 30 \mathrm{~s}\right)$ and final extension for $\left(72{ }^{\circ} \mathrm{C}\right.$ for $10 \mathrm{~min})$.

\section{Analysis of the PCR products}

The PCR product was electrophoresed on 1\% agarose gel in $1 \mathrm{x}$ Tris Borate Ethylenediaminetetraacetic acid (EDTA) buffer stained with gel red and was visualized under UV transilluminator to confirm that a fragment of the correct size had been amplified. Automated sequencing of 16S rRNA genes of the organism was done using the $\mathrm{AB} 35100 \times \mathrm{L}$ genetic analyzer (Thermo Fisher Scientific, USA). Sequencing reaction was performed according to the manufacturer's protocol using Big Dye version 3.1 dye terminator cycle sequencing kit (Applied Biosystems) with $27 \mathrm{f}$ and $1492 \mathrm{r}$ primers. The sequence was aligned in the Gene bank database using Basic Local Alignment Search Tool (BLASTN) program at the National Centre for Biotechnology Information (NCBI) and percent homology score was obtained to identify the organism.

\section{Extraction and purification of bioflocculant}

Adopting the modified methods of Chen et al. [18] and Piyo et al. [19], the purification of the extracted bioflocculant was performed. Briefly, after $72 \mathrm{~h}$ of fermentation, the culture broth was centrifuged $(8000 \mathrm{rpm}, 30 \mathrm{~min})$ to remove bacteria cells. One volume of sterile distilled water was added to the supernatant and centrifuged at $8000 \mathrm{rpm}$ for $15 \mathrm{~min}$ to remove insoluble substances. Two volumes of ethanol were later added to the supernatant, stirred and left to stand for $12 \mathrm{~h}$ at $4{ }^{\circ} \mathrm{C}$. The precipitate obtained was vacuum-dried to obtain crude bioflocculant. The crude product was then dissolved in water to yield a solution, to which one volume of chloroform: n-butyl alcohol (5:2 v/v) was added. The mixture was stirred, poured into a separating funnel and allowed to stand for $12 \mathrm{~h}$ at room temperature. Finally, the supernatant was discarded and two volumes of ethanol were added to recover the precipitate and then lyophilized to obtain a purified bioflocculant.

\section{Jar test determination of bioflocculant dosage}

Different concentrations ( 0.1 to $1.0 \mathrm{mg} / \mathrm{mL}$ ) of the purified bioflocculant were prepared and their flocculating activities measured against $4 \mathrm{~g} / \mathrm{L}$ kaolin clay suspension. Exactly $3.0 \mathrm{~mL}$ of $1 \%(\mathrm{w} / \mathrm{v}) \mathrm{CaCl}_{2}$ was added to the different concentrations of the purified bioflocculant and mixed with $100 \mathrm{~mL}$ of kaolin clay suspension in $500 \mathrm{~mL}$ beakers. The solution was rapidly mixed at $160 \mathrm{rpm}$ for $2 \mathrm{~min}$, followed by gradual flocculation at $40 \mathrm{rpm}$ for $2 \mathrm{~min}$ and sedimentation for $5 \mathrm{~min}$. After sedimentation, $2 \mathrm{~mL}$ was gently withdrawn from the upper clarifying phase in order to measure the flocculating activity [20]. The concentration dosage that gave the best flocculating activity was used for subsequent experiment.

\section{Effect of cations on flocculating activity}

The effect of different cations on bioflocculant production was assessed by replacing $\mathrm{CaCl}_{2}$ in the production medium with $\mathrm{Na}^{+}, \mathrm{K}^{+}, \mathrm{Mg}^{2+}, \mathrm{Mn}^{2+} \mathrm{Al}^{3+}$ and $\mathrm{Fe}^{3+}$ using the method of Kurane et al. [17].

\section{Effect of $\mathrm{pH}$ on flocculating activity}

The effect of $\mathrm{pH}$ on flocculating activity of bioflocculant produced was assessed by adjusting the $\mathrm{pH}$ of the production medium using $0.1 \mathrm{M} \mathrm{HCl}$ and $0.1 \mathrm{M} \mathrm{NaOH}$ at the $\mathrm{pH}$ range of 3-12. [10].

\section{Effect of temperature on flocculating activity}

Heat stability was evaluated by incubating the bioflocculant solutions in water bath at a temperature range of 50, 60, 70, 80, 90 and $100{ }^{\circ} \mathrm{C}$ for $25 \mathrm{~min}$. Afterwards, the residual flocculating activity was determined using the protocol of Gong et al. [21].

\section{Fourier transform infrared spectroscopy (FTIR) analysis}

The purified bioflocculant was subjected to FTIR analysis using FTIR Spectrophotometer Attenuated Total Reflectance (FTIR-ATR) (Perkin Elmer Spectrum 100 , USA). Exactly $5 \mathrm{mg}$ of the dried bioflocculant was pulverized with potassium bromide and forced into bits for FTIR spectral measurement in the frequency range of $4000-650 \mathrm{~cm}^{-1}$.

\section{Thermo-Gravimetric Analysis (TGA) and SEM analysis}

The pyrolysis profile of the purified bioflocculant was monitored with a Simultaneous Thermal Analyser 
(Perkin Elmer STA 6000 Germany, USA). The surface morphology structure of the purified bioflocculant was examined using Scanning Electron Microscopy (SEM) (JEOL-JSM-6390LV, Japan).

\section{Chemical composition of the bioflocculant}

The total sugar content was determined by phenolsulphuric acid method using glucose as standard [22]. The protein content of the purified bioflocculant was determined by the Lowry method with serum albumin (BSA) used as the standard [23].

\section{Lab-scale studies of bioflocculant produced by Arthrobacter humicola in sewage waste water treatment}

The sewage waste water collected from the waste water treatment plant, Phuthaditjabha, Eastern Free State Province, South Africa, was used to validate the flocculating efficiency of the test bioflocculant. Different physiological parameters like $\mathrm{pH}$, suspended solids, biological oxygen demand BOD, turbidity, COD and nitrate of the water sample were measured before and after treatment. Optimum dose of $0.8 \mathrm{mg} / \mathrm{mL}$ of the purified bioflocculant and $3 \mathrm{~mL}$ of $1 \% \mathrm{CaCl}_{2}$ were added into $100 \mathrm{~mL}$ of sewage waste water. The contents were agitated at $160 \mathrm{rpm}$ for $2 \mathrm{~min}$ using jar test and the speed was later reduced to $40 \mathrm{rpm}$ for $2 \mathrm{~min}$ to facilitate floc formation. The treated samples were left to settle for $5 \mathrm{~min}$ and the supernatant was used for further physiological analyses. This procedure was conducted in triplicates. The turbidity, suspended solids, COD and nitrate were measured using spectrophotometer DR 3800 and turbidimiter (HACH, USA). The removal efficiencies were thereafter calculated as:

$$
R E=\left[\frac{A_{o}-A}{A_{o}}\right] \times 100
$$

Where Ao and A are the initial and final values obtained before and after treatment respectively.

To assay for the BOD, $25 \mathrm{~mL}$ of raw and $50 \mathrm{~mL}$ of treated waste water samples were added into BOD bottle and the bottles were filled up with BOD buffer (2.25\% $\mathrm{MgSO}_{4} .7 \mathrm{H}_{2} \mathrm{O}, 2.75 \% \mathrm{CaCl}_{2}, 0.025 \% \mathrm{FeCl}_{3} .6 \mathrm{H}_{2} \mathrm{O}$ and phosphate buffer solution). The BOD buffer was used as the initial working solution. The bottles were incubated at $20{ }^{\circ} \mathrm{C}$ for 5 days. The initial and final dissolved oxygen (DO) were measured after $15 \mathrm{~min}$ and 5 days respectively using a HI5421 BOD Meter (Hanna, USA). The BOD and the percentage BOD removal efficiency were subsequently estimated using the equations:

$$
B O D=\frac{D_{1}-D_{2}}{P}
$$

$\mathrm{D}_{1}=\mathrm{DO}$ in diluted specimen after preparation

$$
\begin{aligned}
& \mathrm{D}_{2}=\mathrm{DO} \text { after } 5 \text { days } \\
& \mathrm{P}=\text { decimal fraction of specimen used } \\
& R E(\%)=\frac{B_{1}-B_{2}}{B_{1}} \times 100 \\
& \mathrm{~B}_{1}=\text { Untreated sample } \\
& \mathrm{B}_{2}=\text { Treated sample }
\end{aligned}
$$

\section{Statistical analysis}

Results were expressed as mean value \pm standard deviation of three replicates and were subjected to one way analysis of variance (ANOVA) followed by Duncan multiple range tests to determine significant differences in all the parameters using SPSS version 16.0. Values were considered statistically significant at $p<0.05$.

\section{Results and discussion}

\section{Molecular identification of bioflocculant producing} organism

Ten actinobacteria strains were isolated from soil sediment of Sterkfontein dam and were assessed for flocculating efficiency. Strain SFD 07 which demonstrated highest flocculating efficiency of $85 \%$ against kaolin clay suspension was selected for further experiment. The $16 \mathrm{~S}$ rDNA PCR yielded a product of expected size (approximately $1.5 \mathrm{~kb}$ ). Basic Local Alignment Search Tool (BLAST) analysis of the nucleotide sequence of the $16 \mathrm{~S}$ rDNA revealed the bacteria to have $99 \%$ similarity to Arthrobacter humicola strain $R 1$ and the sequence was deposited in the Gene bank as Arthrobacter humicola with accession number KC816574.1.

\section{Effect of bioflocculant dosage on flocculation}

The data obtained with respect to the flocculating efficiency over the dosage range of 0.1 to $1.0 \mathrm{mg} / \mathrm{mL}$ of the purified bioflocculant is shown in Fig. 1. The flocculating efficiency was a bit weaker at lower concentrations $(0.1-0.7 \mathrm{mg} / \mathrm{mL})$. It is however noteworthy that the maximum flocculating efficiency (89\%) was observed at $0.8 \mathrm{mg} / \mathrm{mL}$ dose and this was choose as the best (optimal) concentration for the successive assays. Further increase in bioflocculant dosage resulted in a decline in flocculating activity. Insufficient dosage of bioflocculant will hinder or affect bridging mechanism formation of flocs and over dosage will result into high viscosity formation which will inhibit sedimentation of suspended particles by restabilising the kaolin particles. Hence, establishing the optimum bioflocculant dosage is an important parameter in flocculation. Our assertion in this study on the effect of dosage on flocculation is not only significant but also agrees with the report of Ugbenyen and Okoh [24], where the bioflocculant produced by the consortium of Cobetia spp and Bacillus sp 


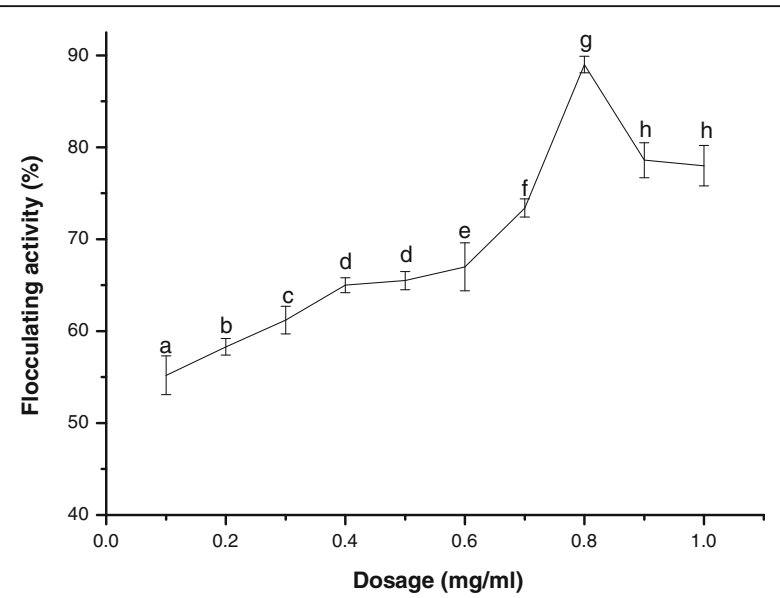

Fig. 1 Effect of concentration on flocculating activity. Percentage flocculating activities with different alphabetic letters are significantly different $(p<0.05)$

attained its optimum flocculating activity of $90 \%$ at concentration dosage of $0.8 \mathrm{mg} / \mathrm{mL}$. In contrast to the present study, the bioflocculant produced by $C$. daeguense was more than $90 \%$ in the range of $0.3-8.2 \mathrm{mg} / \mathrm{L}$ and the maximum value achieved $96.9 \%$ at bioflocculant dosage of $1.2 \mathrm{mg} / \mathrm{L}$ at optimal pH 5.6 and temperature of $15^{\circ} \mathrm{C}$ [25].

\section{Effects of cations on bioflocculant production}

The effect of metal ion on purified bioflocculant is shown in Table 1. Cation had played an important function in flocculation by neutralizing and stabilizing the negative charges of both functional groups of kaolin clay suspension and bioflocculant [26]. The results of this study demonstrated that all the cations tested stimulated the flocculating activity of the bioflocculant produced against kaolin clay suspension with the exception of monovalent cations. Interestingly, the highest flocculating activity was observed with divalent cations $\left(\mathrm{Ca}^{2+}\right.$ and $\left.\mathrm{Mg}^{2+}\right)$ which agrees with the report of Kumar et al. [27] where flocculating efficiency of bioflocculant produced by a haloalkaliphic

Table 1 Effect of cations on flocculating activity $(n=3$, mean \pm SD)

\begin{tabular}{ll}
\hline CATIONS & FLOCCULATING ACTIVITY (\%) \\
\hline $\mathrm{Fe}^{3+}$ & $57.90 \pm 0.4^{\mathrm{a}}$ \\
$\mathrm{Al}^{3+}$ & $65.30 \pm 0.6^{\mathrm{b}}$ \\
$\mathrm{K}^{+}$ & $33.10 \pm 1.6^{\mathrm{c}}$ \\
$\mathrm{Mg}^{2+}$ & $88.70 \pm 0.9^{\mathrm{d}}$ \\
$\mathrm{Na}^{+}$ & $41.70 \pm 1.5^{\mathrm{e}}$ \\
$\mathrm{Mn}^{+}$ & $75.70 \pm 2.25^{\mathrm{f}}$ \\
$\mathrm{Ca}^{2+}$ & $89.00 \pm 0.7^{\mathrm{d}}$ \\
\hline
\end{tabular}

Percentage flocculating activities with different superscripts are significantly different $(p<0.05)$
Bacillus sp. was enhanced in the presence of $\mathrm{Ca}^{2+}, \mathrm{Cu}^{2+}$ and $\mathrm{Zn}^{2+}$ which are representatives of divalent cations. It is noteworthy that the divalent cations appear to enhance the neutralization of negative charges on kaolin clay suspension and the bioflocculant thereby minimizing the gap in between and enhancing the adsorption of bioflocculant to the surface of the kaolin clay which led to agglomeration of flocs development and better sedimentation of the kaolin clay [28].

\section{Effect of $\mathrm{pH}$}

The result of the influence of $\mathrm{pH}$ (over a range of 3-12 scale) on the flocculating activity is presented in Fig. 2. This study demonstrates that acidic and basic $\mathrm{pH}$ media support flocculating efficiency by the test organism, with the most pronounced activity observed in the basic medium. This observation corroborates the fact that bioflocculants exhibit varying degree of electrical states at different $\mathrm{pH}$ which impact on the flocculating activity of the bioflocculant for kaolin particles [29]. The best and most potent flocculating activity (91\%) was observed at the highest $\mathrm{pH}$ scale value $(\mathrm{pH} 12)$ and this corroborates the report of Li et al. [30], where bioflocculant produced by Arthrobacter sp. B4 attained its maximum flocculating activity at $\mathrm{pH} 12$. In another study, the alkaline $\mathrm{pH}$ range of 7-12 favoured the bioflocculant produced by Bacillus megaterium and maximum yield of bioflocculant was obtained at $\mathrm{pH} 9$, while it was inhibited in an acidic culture medium [28].

\section{Effect of temperature}

The behaviour of the bioflocculant when exposed to heat is shown in Fig. 3. More than $80 \%$ flocculating activity was retained at $50-70{ }^{\circ} \mathrm{C}$ after heating the bioflocculant for $25 \mathrm{~min}$. However, there was stability in the flocculating

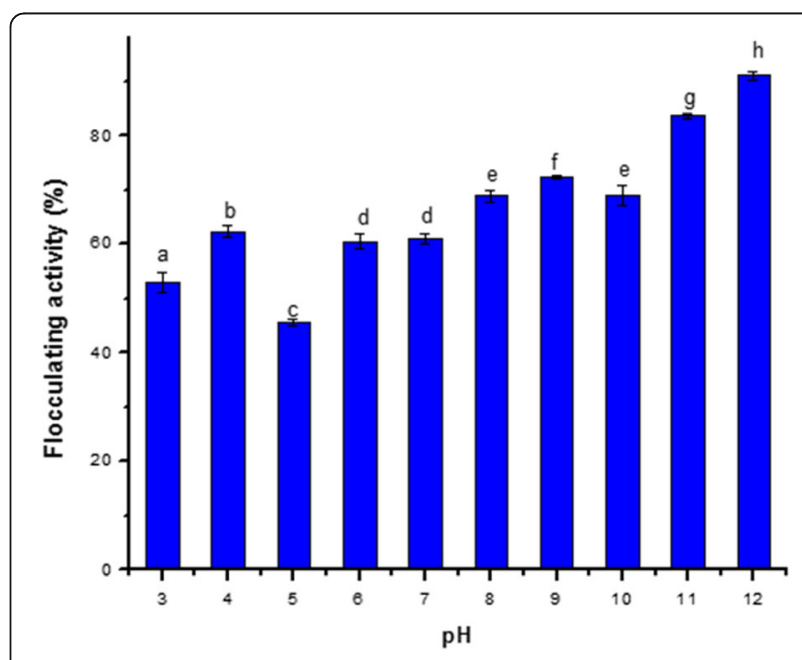

Fig. 2 Effect of $\mathrm{pH}$. Bars with different superscript for the parameter are significantly different $(p<0.05)$ 


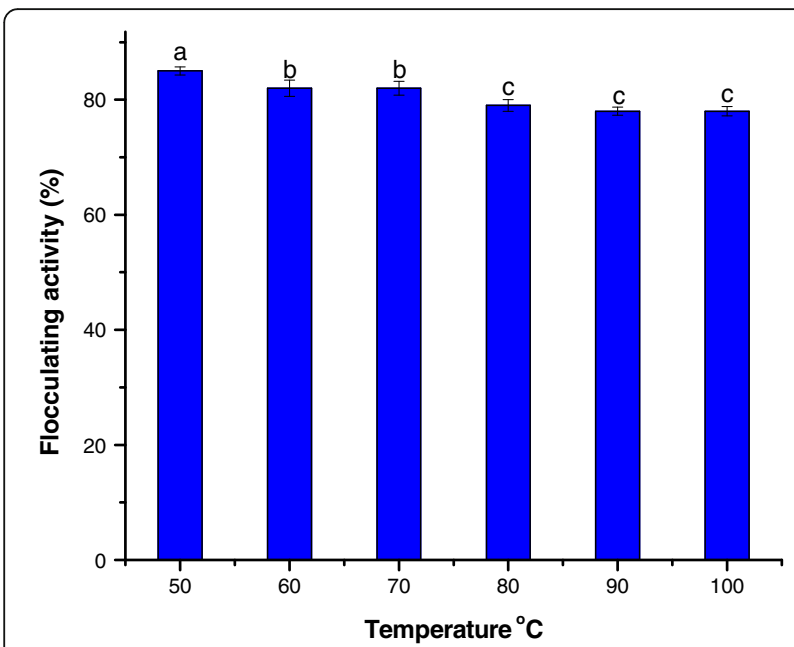

Fig. 3 Thermal stability of bioflocculant produced by Arthrobacter humicola. Bars with different superscripts are significantly different $(p<0.05)$

activity over a temperature range of $80-100{ }^{\circ} \mathrm{C}$. It is noteworthy that based on the structure of bioflocculant, more than $78 \%$ flocculating activity was retained after heating the purified bioflocculant for $25 \mathrm{~min}$ at the highest temperature $\left(100{ }^{\circ} \mathrm{C}\right)$. Hence, this result suggests that the main backbone of the bioflocculant is a polysaccharide. Likewise, the results of the biochemical analyses of the purified bioflocculant confirmed that $82 \%$ of polysaccharide were detected with no presence of protein in the structure. This observation is not only outstanding but also affirmed that the main backbone of the purified bioflocculant structure is a polysaccharide, which is supportive of its excellently elicited flocculating activities in this study. This is consistent with the reported findings that flocculants rich in polysaccharide are more heat stable than those composed of mainly protein and nucleic acids [10, 31, 32].

\section{Application of the purified bioflocculant in the treatment of sewage waste water}

The discharge of untreated or partially treated sewage water containing non-biodegradable materials, heavy metals and other toxicants complicates the degree of contamination of the receiving water bodies. This challenge has necessitated the need for proper treatment of various effluents prior to discharge into receiving water body. In addition, sewage carries an array of pathogenic microbes of clinical importance. During the course of decomposing the organic materials in water bodies, the availability of dissolved oxygen gets depleted and can lead to the death of many species of fish and other aquatic life forms [33]. Having validated the flocculating efficiency of our test bioflocculant against kaolin clay suspension, its potential in treating sewage effluent
Table 2 Physicochemical characteristics of sewage waste water before and after treatment with purified bioflocculant

\begin{tabular}{lll}
\hline Parameter & BT & AT \\
\hline pH & $7.73 \pm 0.24$ & $7.88 \pm 0.56$ \\
Turbidity (NTU) & $128 \pm 1.12$ & $24.0 \pm 0.84$ \\
SS $\left(\mathrm{mgL}^{-1}\right)$ & $201 \pm 1.40$ & $89.0 \pm 1.23$ \\
Nitrate $\left(\mathrm{mgL}^{-1}\right)$ & $8.40 \pm 0.27$ & $2.40 \pm 0.72$ \\
COD $\left(\mathrm{mgL}^{-1}\right)$ & $1360 \pm 1.74$ & $467 \pm 1.32$ \\
BOD $\left(\mathrm{mgL}^{-1}\right)$ & $49.20 \pm 0.18$ & $17.92 \pm 0.64$
\end{tabular}

Values are expressed as means \pm standard deviation of triplicate determinations

NTU Nephelometric turbidity units

$C O D$ Chemical oxygen demand

$B O D$ Biological oxygen demand

SS Suspended solids

BT Before treatment

AT After treatment

waste water was examined and the physicochemical properties are presented in Table 2. From the results (Table 2), it is evident that the bioflocculant produced by Arthrobacter humicola significantly reduced the degree of turbidity and removed nitrate, COD, BOD and the total suspended solids at removal efficiencies of $81.3 \%$, $71.4 \%, 65.7 \%, 63.5 \%$ and $55.7 \%$ respectively (Table 2 ). The use of microbial flocculants in the treatment of waste water has been well documented. For instance, the bioflocculant produced by Bacillus mucilaginosus was able to remarkably remove COD, BOD and suspended solids in domestic, brewery and pharmaceutical waste waters and was a suitable alternative to the synthetic flocculants [34]. Similarly, the bioflocculant produced from $A$ indicus CAN was able to reduce BOD, COD and suspended in waste water samples in the range of $38-80 \%, 37-79 \%$ and $41-68 \%$ respectively at a bioflocculant dosage of $500 \mathrm{mg} / \mathrm{L}$ [35]. Hence, the observations on the

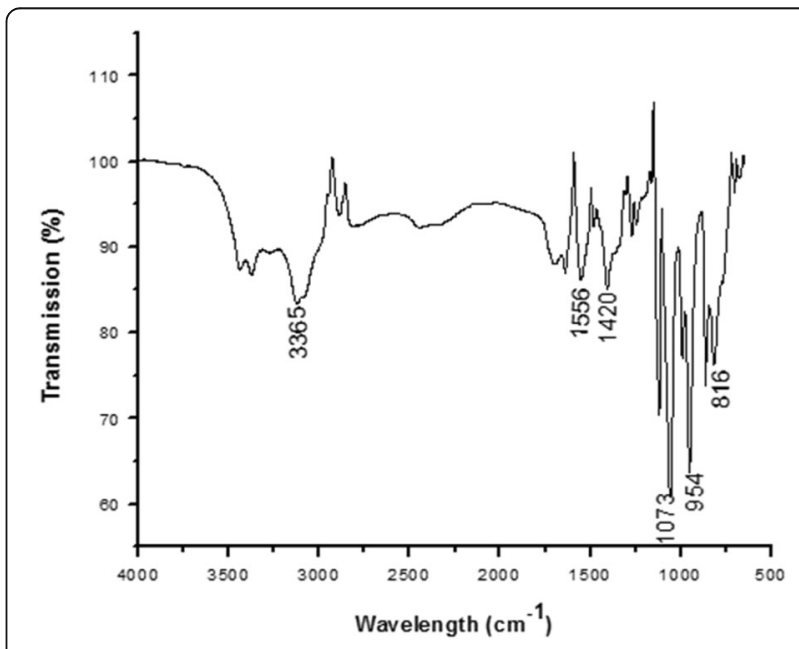

Fig. 4 Fourier-transform infrared spectrogram of purified bioflocculant produced by Arthrobacter humicola 


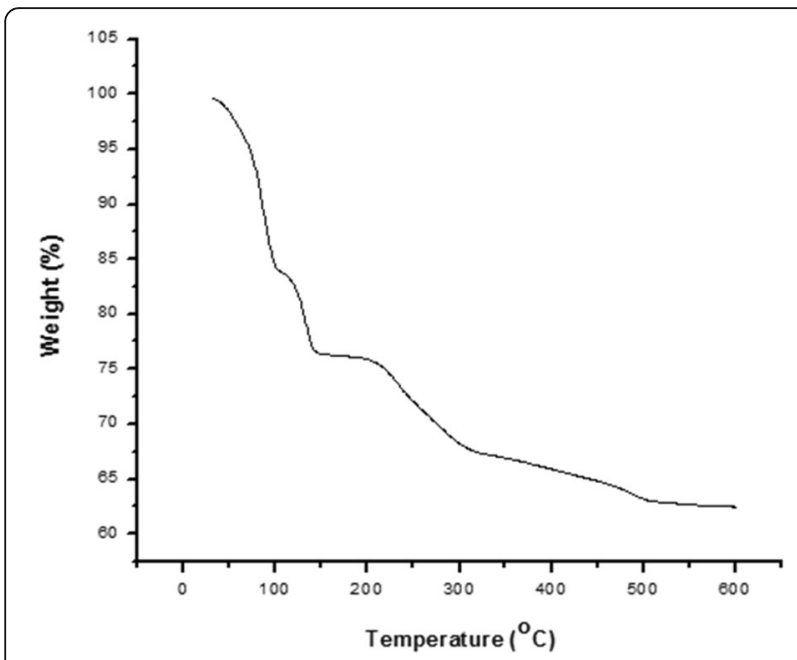

Fig. 5 Thermogravimetric analysis of purified bioflocculant

purified bioflocculant used in this study are confirmative that the test bioflocculant could serve as an alternative coagulant to chemical flocculants and can be employed in waste water treatment prior to discharge into water bodies.

\section{Fourier transform infrared spectroscopy of the purified bioflocculant}

Presented in Fig. 4 is the result of the FTIR study of the investigated bioflocculant. The spectrum of the purified bioflocculant exhibited a band at $3365 \mathrm{~cm}^{-1}$ which is descriptive of a hydroxyl group. The band at $1420 \mathrm{~cm}^{-1}$ could be assigned to the symmetrical stretching in the carboxylate, indicating the presence of uronate in the purified bioflocculant [36]. The peak at $1073 \mathrm{~cm}^{-1}$ is characteristic of $\mathrm{C}-\mathrm{O}$ groups suggesting the presence of carboxyl group in the purified bioflocculant [37]. Furthermore, the absorption bands at 954 and $816 \mathrm{~cm}^{-1}$ respectively are suggestive of sugar derivatives. Xiong et al. [10] reported that the small absorption peak is associated with
B-glycosidic linkages and sugar monomers. The occurrence of carboxyl and hydroxyl functional groups suggests adsorption positions for suspended particles and has been opined to be the best choice of functional groups for flocculation process [38]. Interesting, the results of the biochemical analyses of the purified bioflocculant for carbohydrate and proteins revealed it contains $82 \%$ polysaccharide with no detection of protein in the structure. This observation is not only remarkable but also confirms that the main backbone of the purified bioflocculant structure is a polysaccharide, which is supportive of its excellently elicited flocculating activities in this study.

\section{Thermogravimetric analysis of purified bioflocculant}

The pyrolysis profile of the bioflocculant was examined using thermogravimetric analyzer. As shown in Fig. 5, there was a decomposition at 50 and $140{ }^{\circ} \mathrm{C}$ and about $77 \%$ weight was retained. The initial loss in weight could be attributed to moisture content of the bioflocculant. Furthermore, when the temperature was increased from 150 to $500{ }^{\circ} \mathrm{C}$, there was a decrease of about $27 \%$ mass fraction which could occur as a release of volatile hydrocarbons from the heat decomposition of the polysaccharides in the purified bioflocculant [39]. However, further increase from 500 to $600{ }^{\circ} \mathrm{C}$ demonstrated that the purified bioflocculant weight was retained. Thus, affirming the main component of the material to be polysaccharide.

\section{SEM and EDX analysis}

The micrographs of the morphological structure of the purified bioflocculant and its interaction with kaolin clay suspension using Scanning Electron Microscope are shown in Fig. 6. While the purified bioflocculant appeared as whitish flakes structure (Fig. 6a), the interaction of the purified bioflocculant and the kaolin particles resulted into compacted floc formation (Fig. 6b). This was so because the kaolin particles were adsorbed on the binding sites of the purified bioflocculant and the

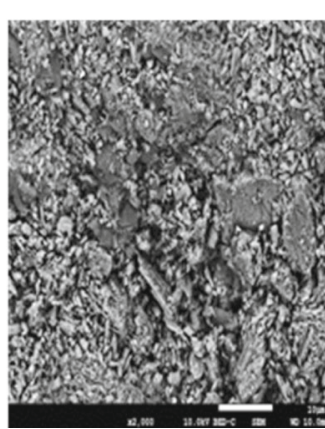

a Purified

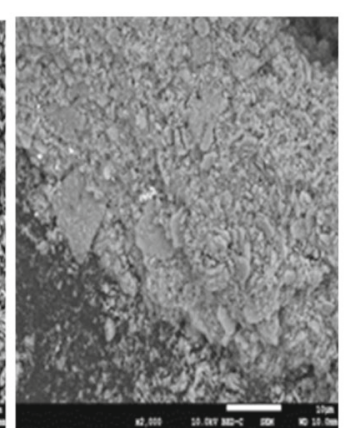

b Flocculated

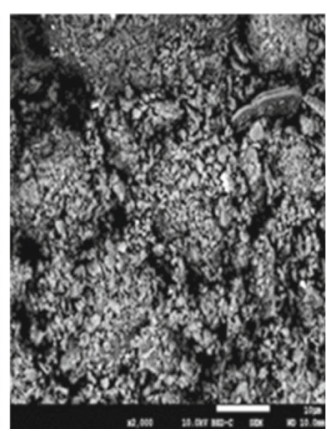

C Kaolin clay suspension

Fig. $\mathbf{6}$ Scanning electron micrographs of $\mathbf{a}$ purified $\mathbf{b}$ flocculated $\mathbf{c}$ Kaolin clay suspension 
subsequent interactions resulted into agglomeration of larger flocs (Fig. 6b). The EDX analysis confirmed the following proportions $\mathrm{C}$ : O: Na: P: K with 13.90: 41.96: 26.79: 16.61: 0.74 weight percentage respectively.

\section{Conclusions}

The bioflocculant investigated in this study is made up of polysaccharide as its main backbone and demonstrates good flocculating efficiency against kaolin clay. FTIR spectral analysis demonstrated the presence of carboxyl and hydroxyl moieties as the major functional groups. The high flocculating activity demonstrated by the bioflocculant coupled with the removal of COD, BOD, turbidity, SS and nitrate at better efficiencies suggested its industrial application in waste water treatment. There are ongoing investigations within our research group on its oral toxicological assessment and large scale production.

\section{Abbreviations \\ BLAST: Basic local alignment search tool; BOD: Biological oxygen demand; BSA: Bovine serum albumin; COD: Chemical oxygen demand; DNA: Deoxyribonucleic acid; EDX: Energy dispersive X-ray; FA: Flocculating activity; FTIR: Fourier transformer infrared spectroscopy; NCBI: National center for biotechnological information; OD: Optical density; PCR: Polymerase chain reaction; RNA: Ribonucleic acid; SEM: Scanning electron microscope; TGA: Thermogravimetric analyzer; YMA: Yeast malt extract agar}

\section{Acknowledgements}

We thank William Peter for his excellence technical assistance.

\section{Funding}

We are grateful to National Research Foundation of South Africa (NRF) for their financial supports under the Grant UID: 94923.

\section{Availability of data and materials}

The positive isolate was isolated, identified, maintained and studied at Microbial Biotechnology Laboratory. The data generated regarding the identification of the organism was available in Genbank with accession number KC816574.1.

\section{Authors' contributions}

AMO; Executed the research experiment and drafted the manuscript. EVH; CHP and AOT; designed and supervised the research as well as proof read the final version of the manuscript. All authors read and approved the final submission of the manuscript.

\section{Competing interests}

The authors declare that they have no competing interests.

\section{Consent for publication}

Not applicable.

Ethics approval and consent to participate

Not applicable.

\section{Publisher's Note}

Springer Nature remains neutral with regard to jurisdictional claims in published maps and institutional affiliations.
Received: 1 March 2017 Accepted: 7 June 2017

Published online: 12 June 2017

\section{References}

1. Rout C, Sharma A. Assessment of drinking water quality: a case study of Ambala cantonment area, Haryana, India. Inter J Environ Sci. 2011;2:2. 2.

2. Prasertsan P, Dermlim W, Doelle H, Kennedy JF. Screening, characterization and Flocculating property of carbohydrate polymer from newly isolated Enterobacter cloac WD7. Carbohydr Polym. 2006;66:289-97.

3. Shih IL, Van YT. The production of poly-(gamma-glutamic acid) from microorganisms and its various applications. Bioresour Technol. 2001;79: 207-25

4. Zhang J, Liu Z, Wang S, Jiang P. Characterization of a bioflocculant produced by the marine Myxobacterium nannocystis sp. NU-2. Appl Microbiol Biotechnol. 2002;59:517-22.

5. Deng SB, Bai RB, Hu XM, Luo Q. Characteristics of a bioflocculant produced by Bacillus mucilaginosus and its use in starch wastewater treatment. Appl Microbiol Biotechnol. 2003;60:588-93.

6. He N, Li Y, Chen J. Production of a novel polygalacturonic acid bioflocculant REA- 11 by Corynebacterium glutamicum. Bioresour Technol. 2004:94:99-105.

7. Lixi Y, Chunling M, Zhenming C. Bioflocculant produced by Klebsiella sp. MY and its application in the treatment of oil-field produced water. J Ocean Univ China. 2006:5:333-8.

8. Yokoi H, Yoshida T, Mori S, Hirose J, Hayashi S, Takasaki Y. Biopolymer flocculant produced by an Enterobacter sp. Biotechnol Lett. 1997;19:569-73.

9. Wang Y, Gao BY, Yue QY, Wei JC, Zhou WZ, Gu R. Color removal from textile industry wastewater using composite flocculants. Environ Technol. 2010;28:629-37.

10. Xiong Y, Wang Y, Yu Y, Li Q, Wang H, Chen RC. Production and characterization of a novel bioflocculant from Bacillus licheniformis. Appl Environ Microbiol. 2010;76:2778-82.

11. Ghosh M, Pathak S, Ganguli A. Application of a novel biopolymer for removal of Salmonella from poultry wastewater. Environ Technol. 2009; 30:337-44.

12. Bajaj IB, Singhal RS. Flocculation properties of poly ( $\gamma$ - Glutamic Acid) produced from Bacillus subtilis isolate. Food Bioprocess Technol. 2011;4:745-52.

13. Westerberg K, Annelie M, Erko Stackebrandt E, Janet K. Arhtrobacter chlorophenolicus sp. nov., a new species capable of degrading high concentrations of 4- chlorophenol. Int J Syst Evol Microbiol. 2000;50:2083-92.

14. Kotouckova L, Schumann P, Durnova E, Sproer C, Sedlacek I, Neca J. Arthrobacter nitroguajacolicus sp. nov., a novel 4-nitroguaiacol-degrading actinobacterium. Int J Syst Evol Microbiol. 2004;54:773-7.

15. Jensen PR, Dwight R, Fenical W. Distribution of actinomycetes in near Shore tropical marine sediments. Appl Environ Microbiol. 1991;57:1102-8.

16. Xia S, Zhang Z, Wang X, Yang A, Chen L, Zhao J, Jianfu Z. Production and characterization of a bioflocculant by Proteus mirabilisTJ-1. Bioresour Technol. 2008;99:6520-7.

17. Kurane R, Matsuyama H. Production of a bioflocculant by mixed culture Biosci Biotechnol Biochem. 1994;58:1589-94

18. Chen H, Zhang JF, Jiang PJ, Yang SL, Liu ZL. Composition and Characterization of microbiological flocculant SC06. Environ Chem. 2002;21:360-4.

19. Piyo N, Cosa S, Mabinya LV, Okoh Al. Assessment of bioflocculant production by Bacillus sp. Gilbert, a marine bacterium isolated from the bottom sediment of Algoa Bay. Mar Drugs. 2011:9:1232-42.

20. Lee SH, Shin WS, Shin MC, Choi SJ, Park LS. Improvement of water treatment performance by using polyamine flocculants. Environ Technol. 2001;22:653-9.

21. Gong W, Wang S, Sun X, Liu X, Yue Q, Gao B. Bioflocculant production by culture of Serratia ficaria and its application in wastewater treatment. Bioresour Technol. 2008;99:4668-74.

22. Dubois M, Gilles KA, Hamilton JK, Rebers PA, Smith F. Colorimetric method for determination of sugars and related substances. Anal Chem. 1956;28: 350-6.

23. Lowry OH, Rosebrough NJ, Farr AL, Randall RJ. Protein measurement with the Folin Phenol reagent. J Biol Chem. 1951;193:265-75.

24. Ugbenyen AM, Okoh Al. Characteristics of a bioflocculant produced by a consortium of Cobetia and Bacillus species and its application in the treatment of wastewaters. Water SA. 2014;40:139-44.

25. Liu L, Chen W. Characteristics and culture conditions of a bioflocculant produced by Penicillium sp. Biomed Environ Sci. 2010;23:213-8. 
26. Wu J, Ye HF. Characterization and flocculating properties of an extracellular biopolymer produced from a Bacillus subtillis DYU1 isolate. Proc Biochem. 2007:42:1114-23.

27. Kumar CG, Joo HS, Kavali S, Choi JW, Chang CS. Characterization of an extracellular biopolymer flocculant from a haloakalophilic Bacillus isolate. World J Microbiol Biotechnol. 2004;20:837-43.

28. Zheng Y, Ye ZL, Fang XL, Li YH, Cai WM. Production and characteristics of a bioflocculant produced by Bacillus sp. F19. Bioresour Technol. 2008;99:7686-91.

29. Pan YZ, Shi B, Zhang Y. Research on flocculation property of bioflocculant PG.a21 Ca. Mod Appl Sci. 2009;3:106-12.

30. Li Y, Li Q, Hao D, Hu Z, Song D, Yang M. Characterization and flocculation mechanism of an alkali-activated polysaccharide flocculant from Arthrobacter sp. B4. Bioresour Technol. 2014;170:574-7.

31. Gao Q, Zhu XH, Mu J, Zhang Y, Dong XW. Using Ruditapes philippinarum conglutination mud to produce bioflocculant and its applications in wastewater treatment. Bioresour Technol. 2009;100:4996-5001.

32. Wang L, Ma F, Lee D, Wang A, Ren N. Bioflocculants from hydrolysates of corns stover using isolated strain Ochrobactium cicero W2. Bioresour Technol. 2013;145:259-63.

33. Mbwele LA. Microbial phosphorus removal in waste stabilisation pond wastewater treatment systems. Ph.D. Dissertation. Stockholm: Royal Institute of Technology School of Biotechnology; 2006.

34. Lian B, Ye C, Jin Z, Teng HH, Zhu L, Yua S. Microbial flocculation by Bacillus mucilaginosus: applications and mechanisms. Bioresour Technol. 2008;99: 4825-31.

35. Patil SV, Patil CD, Salunke BK, Salunkhe RB, Bathe GA, Patil DM. Studies on characterization of bioflocculant exopolysaccharide of Azotobacter indicus and its potential for wastewater treatment. Appl Biochem Biotechnol. 2011; 163:463-72.

36. Okaiyeto K, Nwodo UU, Mabinya LV, Okoh Al. Evaluation of the flocculation potential and characterization of bioflocculant produced by Micococcus sp. Leo Appl Biochem Microbiol. 2014;50:601-8.

37. Ahmad HRA, Azni I, Norhafizah A, Rosfarizan M. Production and characterization of a bioflocculant produced by Aspergillus flavus. Bioresource Technol. 2013;127(1):489-93.

38. Daolun LF, Shinhong HX. Characterization of bioflocculant MBF33-3 produced by an isolated Bacillus sp. World J Microbiol Biotechnol. 2008:24: 1627-32.

39. Yim JH, Kim SJ, Ahn SH, Lee HK. Characterization of novel bioflocculant, p- KG03, from a marine dinoflagellate, Gyrodium impudicum KG03. Bioresour Technol. 2007:98:361-7.

\section{Submit your next manuscript to BioMed Central and we will help you at every step:}

- We accept pre-submission inquiries

- Our selector tool helps you to find the most relevant journal

- We provide round the clock customer support

- Convenient online submission

- Thorough peer review

- Inclusion in PubMed and all major indexing services

- Maximum visibility for your research

Submit your manuscript at www biomedcentral.com/submit

) Biomed Central 